\title{
Aquabacterium fontiphilum sp. nov., isolated from spring water
}

\author{
Mei-Chun Lin, ${ }^{1}$ Sing-Rong Jiang, ${ }^{1}$ Jui-Hsing $\mathrm{Chou}^{2}{ }^{2}$ A. B. Arun, ${ }^{2}$ \\ Chiu-Chung Young ${ }^{2}$ and Wen-Ming Chen ${ }^{1}$
}

Correspondence Wen-Ming Chen p62365@ms28.hinet.net

\author{
${ }^{1}$ Laboratory of Microbiology, Department of Seafood Science, National Kaohsiung Marine \\ University, 142 Hai-Chuan Rd, Nan-Tzu, Kaohsiung City 811, Taiwan, ROC \\ ${ }^{2}$ Department of Soil Environmental Science, College of Agriculture and Natural Resources, National \\ Chung Hsing University, Taichung, Taiwan, ROC
}

\begin{abstract}
A short-rod-shaped, Gram-negative, motile bacterial strain, designated CS- $6^{\top}$, was isolated from a water sample collected from a spring located inside Nature Valley, Hsinchu County, Taiwan, and was characterized using a polyphasic approach. Phylogenetic analyses based on 16S rRNA gene sequences showed that the strain formed a monophyletic branch at the periphery of the evolutionary radiation occupied by the genus Aquabacterium in the class Betaproteobacteria. The closest neighbours were Aquabacterium parvum B6 ${ }^{\top}$ (96.7\% sequence similarity), Aquabacterium commune B8 ${ }^{\top}(96.6 \%)$ and Aquabacterium citratiphilum B4 ${ }^{\top}(95.9 \%)$. The predominant fatty acids were $18: 1 \omega 7 c(30.5 \%), 16: 0(27.9 \%)$ and summed feature 3 $(16: 1 \omega 7 c$ and/or iso-15:0 2-OH) (22.7\%). The DNA-DNA relatedness of the strain with respect to recognized species of the genus Aquabacterium was less than $70 \%$. The isolate was also distinguishable from members of the genus Aquabacterium on the basis of phenotypic and biochemical characteristics. It is evident from the genotypic, chemotaxonomic and phenotypic data, therefore, that strain CS- $6^{\top}$ represents a novel species of the genus Aquabacterium, for which the name Aquabacterium fontiphilum sp. nov. is proposed. The type strain is CS- $6^{\top}$ (=LMG $24215^{\top}=$ BCRC $17729^{\top}$ ).
\end{abstract}

The genus Aquabacterium, proposed by Kalmbach et al. (1999), currently comprises three species with validly published names: Aquabacterium citratiphilum, A. commune and $A$. parvum. The genus Aquabacterium is a member of the order Burkholderiales in the class Betaproteobacteria and encompasses Gram-negative, nonspore-forming, motile rods. The type strains of all three species were isolated from biofilms from the Berlin drinking water system (Kalmbach et al., 1999).

The aim of the present study was to determine the taxonomic position of a bacterial strain (designated CS$6^{\mathrm{T}}$ ), which formed a semi-transparent colony on R2A agar (BD Difco) that had been incubated at $25{ }^{\circ} \mathrm{C}$ for 3 days, following inoculation with a water sample collected from a freshwater spring located in Hsinchu County, Taiwan. The type strains of A. parvum $\left(\mathrm{B}^{\mathrm{T}}\right)$, A. commune $\left(\mathrm{B}^{\mathrm{T}}\right)$ and $A$. citratiphilum $\left(\mathrm{B} 4^{\mathrm{T}}\right)$ were obtained from the Deutsche Sammlung von Mikroorganismen und Zellkulturen (Braunschweig, Germany) and were used as reference strains for comparison. Strain CS- $6^{\mathrm{T}}$ was subjected to a polyphasic taxonomic study.

The GenBank/EMBL/DDBJ accession number for the 16S rRNA gene sequence of strain CS$-6^{\top}$ is EF626687.
Subculturing of strain CS- $6^{\mathrm{T}}$ was performed on R2A agar or a modified version of R2A agar [prepared according to the formula of BD Difco but containing $0.1 \%(\mathrm{v} / \mathrm{v})$ Tween 80 (Sigma) in place of starch] and incubated at $25{ }^{\circ} \mathrm{C}$ for between 48 and $72 \mathrm{~h}$. Strain CS-6 ${ }^{\mathrm{T}}$ was preserved by lyophilization with $20 \%$ (w/v) skimmed milk.

To ascertain the morphology of strain CS- $6^{\mathrm{T}}$, cells were observed using phase-contrast microscopy (DM 2000; Leica) in the lag, exponential and stationary phases of growth. Cell motility was tested using the hanging drop method. The Spot Test flagella stain (BD Difco) was used to stain any flagella that might be present. A Gram-stain set (BD Difco) and the Ryu non-staining $\mathrm{KOH}$ method (Powers, 1995) were used to ascertain the Gram reaction of strain CS- $6^{\mathrm{T}}$. Accumulation of poly- $\beta$-hydroxybutyrate granules was investigated using light microscopy after staining of the cells with Sudan black. Colony morphology was examined using a stereoscopic microscope (SMZ 800; Nikon). The $\mathrm{pH}$ range for growth was examined in $\mathrm{R} 2 \mathrm{~A}$ broth with appropriate biological buffers ( $\mathrm{pH} 4-10$, using increments of $0.5 \mathrm{pH}$ units) (Chung et al., 1995). Tolerance of various $\mathrm{NaCl}$ concentrations was tested in R2A broth prepared according to the formula of BD Difco medium, except that the $\mathrm{NaCl}$ concentration was altered as required 
(0, 0.5 and $1.0-10 \%, \mathrm{w} / \mathrm{v}$, using increments of $1.0 \%)$. Growth at various temperatures $\left(4-45{ }^{\circ} \mathrm{C}\right)$ was measured in R2A broth. Cellular growth was determined by measuring the turbidity $\left(\mathrm{OD}_{600}\right)$ of cultures grown at various $\mathrm{pH}$ values, $\mathrm{NaCl}$ concentrations and temperatures. Anaerobic cultivation was performed on R2A agar or modified R2A agar, using the Oxoid AnaeroGen system.

Extraction of genomic DNA, PCR amplification and sequencing of the 16S rRNA gene were carried out as described previously (Chen et al., 2001). Sequence analysis was performed using a DNA sequencer (ABI Prism 310; Applied Biosystems) and sequence assembly was achieved by using the Fragment Assembly System program from the Wisconsin package (version 8.1) (GCG, 1995). An almostcomplete 16S rRNA gene sequence (1439 nt) from strain CS- $6^{\mathrm{T}}$ was compared with $16 \mathrm{~S}$ rRNA gene sequences available from the Ribosomal Database Project and GenBank databases. Multiple sequence alignment for strain CS- $6^{\mathrm{T}}$ and its closest relatives was performed using BioEdit software (Hall, 1999) and MEGA, version 3.1 (Kumar et al., 2004). Phylogenetic trees were inferred by using the maximum-likelihood (Felsenstein, 1981), maximum-parsimony (Kluge \& Farris, 1969) and neighbour-joining (Saitou \& Nei, 1987) algorithms. An evolutionary distance matrix was generated for the neighbour-joining algorithm by using the distance model of Jukes \& Cantor (1969); bootstrap analysis for the neighbour-joining tree was performed (on the basis of 1000 resamplings) using MEGA, version 3.1 (Kumar et al., 2004). Comparisons of the $16 \mathrm{~S}$ rRNA gene sequence of strain CS- $6^{\mathrm{T}}$ with sequences of members of the genera in the class Betaproteobacteria showed that the strain formed a distinct lineage within the evolutionary radiation of the genus Aquabacterium (Fig. 1), a phyletic line that was supported by all of the tree-making algorithms. The 16S rRNA gene sequence similarity between strain $\mathrm{CS}-6^{\mathrm{T}}$ and the type strains of the members of the genus Aquabacterium ranged from 95.9 to $96.7 \%$. It is also apparent from Fig. 1 that the isolate was loosely associated with A. parvum $\mathrm{B6}^{\mathrm{T}}$ (96.7\% similarity), A. commune $\mathrm{B}^{\mathrm{T}}$ (96.6\% similarity) and $A$. citratiphilum $\mathrm{B}^{\mathrm{T}}$ (95.9\% similarity), although these relationships did not have a high level of bootstrap support (78\%). No other Betaproteobacteria species with validly published names showed more than $96.3 \%$ 16S rRNA gene sequence similarity. It is clear that the divergence values observed with respect to all of the recognized Aquabacterium species $(>3 \%)$ were consistent with separate species status (Stackebrandt \& Goebel, 1994) for strain CS- $6^{\mathrm{T}}$. Further evidence for the separate species status of the strain CS- $6^{\mathrm{T}}$ comes from phenotypic data.

Whole-genome DNA-DNA hybridization experiments were performed using photobiotin-labelled probes, as described by Ezaki et al. (1989). DNA-DNA relatedness was calculated from triplicate experiments. Strain CS- $6^{\mathrm{T}}$ showed $34 \pm 5,23 \pm 5$ and $20 \pm 3 \%$ (means \pm SEM) DNADNA relatedness with respect to $A$. parvum $\mathrm{B}^{\mathrm{T}}$, $A$. citratiphilum $\mathrm{B} 4^{\mathrm{T}}$ and A. commune $\mathrm{B} 8^{\mathrm{T}}$, respectively.

Chemosystematic studies were carried out to establish whether strain CS- $6^{\mathrm{T}}$ had a chemical profile consistent with its assignment to the genus Aquabacterium. Biomass of strain CS- $6^{\mathrm{T}}$ and of type strains of species in the genus Aquabacterium was obtained after growing the strains on modified R2A medium at $25{ }^{\circ} \mathrm{C}$ for 3 days. Fatty acid methyl esters were prepared, separated and identified according to the instructions for the Microbial Identification System (Microbial ID; MIDI) (Sasser, 1990). The DNA G + C content (mol\%) of strain CS- $6^{\text {T }}$

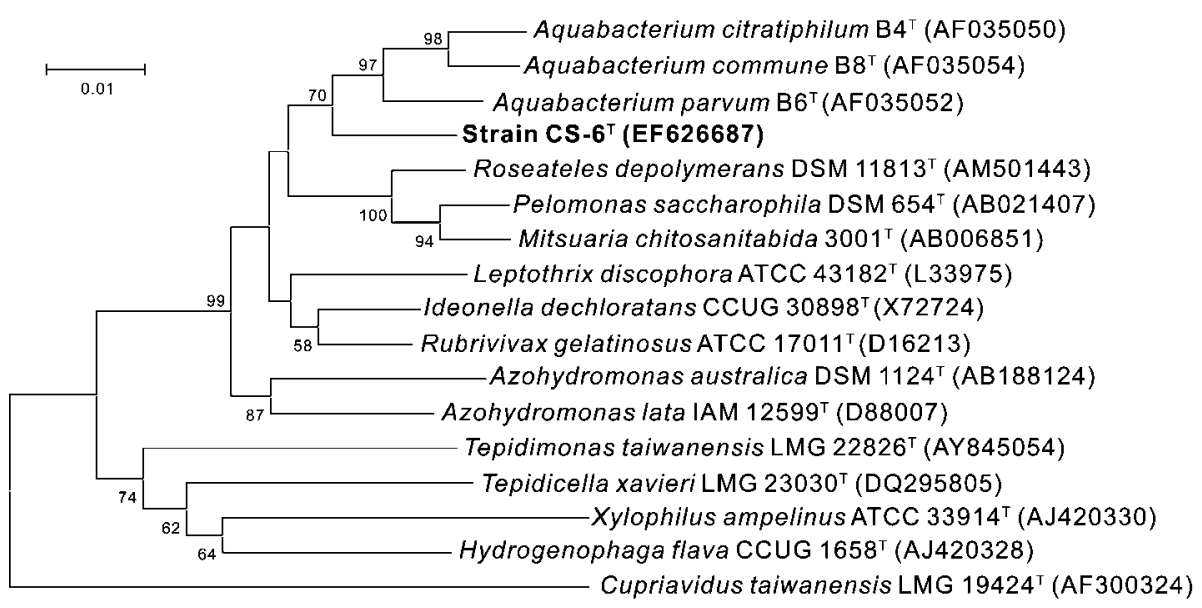

Fig. 1. Phylogenetic tree, based on $16 \mathrm{~S}$ rRNA gene sequences, showing the phylogenetic position of strain CS- $6^{\top}$ and related taxa in the Betaproteobacteria. The neighbour-joining method was employed, with the distance model of Jukes \& Cantor (1969). The sequence of Cupriavidus taiwanensis LMG $19424^{\top}$ was used as an outgroup. Numbers at nodes are bootstrap percentages (based on 1000 resamplings); only values above $50 \%$ are shown. Bar, 0.01 nucleotide substitutions per nucleotide position. 
was estimated (in duplicate) as described by Mesbah et al. (1989). The nucleoside mixture was separated by means of HPLC. The predominant fatty acid constituents of strain

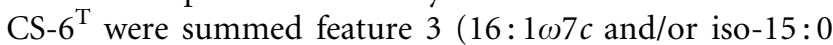
$2-\mathrm{OH}), 16: 0$ and $18: 1 \omega 7 c$. The fatty acid profile of strain CS- ${ }^{\mathrm{T}}$ was generally comparable with those of $A$. citratiphilum $\mathrm{B} 4^{\mathrm{T}}$, A. parvum $\mathrm{B}^{\mathrm{T}}$ and $A$. commune $\mathrm{B} 8^{\mathrm{T}}$, but differed in the proportions of certain fatty acids (Table 1). The DNA G $+\mathrm{C}$ content of strain $\mathrm{CS}-6^{\mathrm{T}}$ was $63.4 \pm 1.0 \mathrm{~mol} \%$ (mean $\pm \mathrm{SEM}$ ), which is consistent with the range of values reported previously for Aquabacterium species (65-66 mol\%) (Kalmbach et al., 1999).

Additional biochemical tests were performed using the API ZYM, API 20NE (both from bioMérieux) and Biolog GN2 microtest systems according to the methods outlined by the manufacturers. The potential utilization of various electron acceptors $\left[\mathrm{KNO}_{3}, \mathrm{KNO}_{2}, \mathrm{NaClO}_{3}, \mathrm{Na}_{2} \mathrm{SO}_{4}\right.$ or iron(III) citrate] was studied as described by Kalmbach et al. (1999). Catalase, oxidase, arginine dihydrolase, urease and lipase (corn oil) activities, nitrate reduction and hydrolysis of starch, casein and Tweens 20, 40,60 and 80 were determined using standard methods (Gerhardt et al., 1994; Lányí, 1987; MacFaddin, 2000). DNase test agar (BD Difco) was used to assay DNase activity. Sensitivity to

Table 1. Fatty acid composition (\%) of strain CS- $6^{\top}(A$. fontiphilum sp. nov.) and the type strains of recognized species of the genus Aquabacterium

Data for A. citratiphilum $\mathrm{B} 4^{\mathrm{T}}$, A. parvum $\mathrm{B} 6^{\mathrm{T}}$ and A. commune $\mathrm{B} 8^{\mathrm{T}}$ were obtained in this study. - , Fatty acids constituting $<1.0 \%$ for all strains.

\begin{tabular}{|lcccc|}
\hline Fatty acid & $\begin{array}{c}\text { Strain } \\
\text { CS-6 }^{\mathbf{T}}\end{array}$ & $\begin{array}{c}\text { A. } \\
\text { citratiphi- } \\
\text { lum } \text { B4 }^{\mathbf{T}}\end{array}$ & $\begin{array}{c}\text { A. } \\
\text { parvum } \\
\text { B6 }^{\mathbf{T}}\end{array}$ & $\begin{array}{c}\text { A. } \\
\text { commune } \\
\mathbf{B 8}^{\mathbf{T}}\end{array}$ \\
\hline $\begin{array}{l}\text { Straight-chain fatty } \\
\text { acids }\end{array}$ & & & & \\
$10: 0$ & - & 1.7 & - & - \\
$12: 0$ & 7.0 & 2.3 & 3.6 & 4.7 \\
$14: 0$ & - & 1.3 & - & - \\
$16: 0$ & 27.9 & 36.5 & 20.1 & 21.3 \\
$18: 0$ & - & - & 9.1 & 2.0 \\
Unsaturated fatty & & & & \\
acids & & & & \\
$18: 1 \omega 7 c$ & 30.5 & 16.0 & 13.4 & 14.0 \\
$18: 1 \omega 9 c$ & 2.0 & 1.6 & 1.6 & - \\
$11-$ Methyl $18: 1 \omega 7 c$ & 1.2 & - & - & - \\
Hydroxy fatty acids & & & & \\
$10: 03-O H$ & 6.5 & 5.9 & 5.4 & 5.1 \\
$12: 0$ 2-OH & - & 2.9 & 2.1 & 1.6 \\
Summed feature $3{ }^{*}$ & 22.7 & 31.9 & 44.0 & 49.5 \\
& & & & \\
\end{tabular}

*Summed features represent groups of two or three fatty acids that cannot be separated by GLC with the MIDI system. Summed feature 3 comprises $16: 1 \omega 7 c$ and/or iso-15:0 2-OH. antibiotics was examined by spreading cells ( $0.5 \mathrm{McFarland}$ standard) on R2A agar and applying discs containing the following antibiotics $(\mu \mathrm{g})$ : ampicillin (10), chloramphenicol (30), gentamicin (10), kanamycin (30), nalidixic acid (30), novobiocin (30), rifampicin (5), penicillin G (10), streptomycin (10), tetracycline (30) and sulfamethoxazole (23.75) plus trimethoprim (1.25). The effects of the various antibiotics on cell growth were assessed after 3 days incubation: susceptibility was scored on the basis of the distance from the edge of the clear zone to the disc. Detailed results from the phenotypic and biochemical analyses of strain CS- $6^{\mathrm{T}}$ are provided in Table 2 and in the species description. Phenotypic characteristics that serve to differentiate strain CS- $6^{\mathrm{T}}$ from its closest relatives are presented in Table 2.

From the above data, it is evident that strain CS- $6^{\mathrm{T}}$ exhibits an overall fatty acid profile that is consistent with those of members of the genus Aquabacterium (Table 1). A phylogenetic analysis based on 16S rRNA gene sequencing confirmed the provisional assignment of strain CS- $6^{\mathrm{T}}$ to the genus Aquabacterium, clearly demonstrating that the strain represents an novel subline. Biochemically, isolate CS- $6^{\mathrm{T}}$ can be differentiated from the most closely phylogenetically and biochemically related species of the genus Aquabacterium (Table 2). On the basis of phenotypic, chemotaxonomic and phylogenetic evidence, therefore, strain CS- $6^{\mathrm{T}}$ represents a novel species within the genus Aquabacterium, for which the name Aquabacterium fontiphilum sp. nov. is proposed.

\section{Description of Aquabacterium fontiphilum sp. nov.}

Aquabacterium fontiphilum [fon.ti.phi'lum. L. n. fons, fontis a spring, fountain; N.L. neut. adj. philum (from Gr. neut. adj. philon) loving; N.L. neut. adj. fontiphilum loving spring-water environment].

Cells are Gram-negative, non-spore-forming rods (0.5$0.8 \mu \mathrm{m}$ wide and $1.0-2.0 \mu \mathrm{m}$ long) that are motile by means of single polar flagella. Colonies on R2A agar are round, elevated with a knob-like protuberance, semitransparent and have irregular edges. Colonies are approximately $1.3-1.5 \mathrm{~mm}$ in diameter on R2A agar after $48 \mathrm{~h}$ incubation at $25{ }^{\circ} \mathrm{C}$. Growth occurs at $15,25,30,37$ and $42{ }^{\circ} \mathrm{C}$, in $0-2 \% \mathrm{NaCl}$ and at $\mathrm{pH} 5-9$. Optimum growth occurs at $25-30{ }^{\circ} \mathrm{C}, 1.0 \% \mathrm{NaCl}$ and $\mathrm{pH}$ 7.0-8.0. Positive for cytochrome oxidase and weakly positive for catalase. Growth is observed under aerobic and microaerophilic conditions. Positive for hydrolysis of urea, gelatin and Tweens 20, 40, 60 and 80. Negative for DNase, lipase (corn oil) and for hydrolysis of skimmed milk, starch and aesculin. Nitrate serves as an alternative electron acceptor, but nitrite, chlorate, sulfate or iron(III) do not. Positive (API ZYM) for alkaline phosphatase, esterase (C4), lipase (C8), lipase (C14), leucine arylamidase, valine arylamidase, cystine arylamidase and naphtholAS-BI-phosphohydrolase, but negative for trypsin, 
Table 2. Genotypic and phenotypic characteristics that distinguish strain $\mathrm{CS}-6^{\top}$ from recognized members of the genus Aquabacterium

All of the results for strain CS- $6^{\mathrm{T}}$ were from this study. Data for A. citratiphilum $\mathrm{B} 4^{\mathrm{T}}$, A. parvum $\mathrm{B} 6^{\mathrm{T}}$ and $A$. commune $\mathrm{B} 8^{\mathrm{T}}$ were obtained in the present study, with the exception of the DNA G + C contents and details of the isolation sources, which were taken from Kalmbach et al. (1999). +, Positive response; -, negative response; w, weak reaction.

\begin{tabular}{|c|c|c|c|c|}
\hline Characteristic & Strain CS-6 ${ }^{\mathrm{T}}$ & A. citratiphilum $\mathrm{B} 4^{\mathrm{T}}$ & A. parvum $\mathrm{B6}^{\mathrm{T}}$ & A. commune $\mathrm{B8}^{\mathrm{T}}$ \\
\hline Isolation source & Spring water & Drinking water & Drinking water & Drinking water \\
\hline Cell size $(\mu \mathrm{m})$ & $0.5-0.8 \times 1-2$ & $0.5 \times 2-4$ & $0.5 \times 1-2$ & $0.5 \times 2-4$ \\
\hline \multicolumn{5}{|l|}{ Growth on/in: } \\
\hline R2A agar & + & + & $\mathrm{W}$ & $\mathrm{w}$ \\
\hline R2A broth & + & + & - & - \\
\hline Nutrient agar & $\mathrm{w}$ & $\mathrm{w}$ & - & - \\
\hline \multicolumn{5}{|l|}{ Hydrolysis of: } \\
\hline Urea & + & + & + & - \\
\hline Casein & - & - & - & + \\
\hline Gelatin & + & + & - & - \\
\hline Arginine dihydrolase & - & + & - & + \\
\hline Alkaline phosphatase & + & + & - & + \\
\hline Lipase $(\mathrm{C} 14)$ & + & + & - & - \\
\hline Valine arylamidase & + & - & - & - \\
\hline Cystine arylamidase & + & - & - & $\mathrm{w}$ \\
\hline$\alpha$-Chymotrypsin & - & + & - & - \\
\hline Naphthol-AS-BI-phosphohydrolase & + & - & + & - \\
\hline \multicolumn{5}{|l|}{ Assimilation of: } \\
\hline i-Erythritol & + & - & - & - \\
\hline Pyruvic acid methyl ester & - & + & - & - \\
\hline Succinic acid monomethyl ester & - & + & - & + \\
\hline cis-Aconitic acid & + & - & - & - \\
\hline Citric acid & + & - & - & - \\
\hline Formic acid & + & - & - & - \\
\hline$\gamma$-Hydroxybutyric acid & - & + & - & - \\
\hline Sebacic acid & - & + & + & - \\
\hline DNA G $+C$ content $(\mathrm{mol} \%)$ & 63.4 & 66 & 65 & 66 \\
\hline
\end{tabular}

$\alpha$-chymotrypsin, acid phosphatase, $\alpha$-galactosidase, $\beta$ galactosidase, $\alpha$-glucosidase, $\beta$-glucosidase, $\beta$-glucuronidase, $N$-acetylglucosaminidase, $\alpha$-mannosidase and $\alpha$ fucosidase. The following compounds are oxidized in the Biolog GN2 test system: Tween 40, Tween 80, i-erythritol, D-mannitol, melibiose, L-rhamnose, D-sorbitol, turanose, acetic acid, cis-aconitic acid, citric acid, formic acid, Dgalactonic acid lactone, D-glucuronic acid, $\beta$-hydroxybutyric acid, itaconic acid, DL-lactic acid, succinamic acid, Lalanine, L-alanyl glycine, L-aspartic acid, L-ornithine, Lpyroglutamic acid, L-glutamic acid, $\gamma$-aminobutyric acid, urocanic acid, uridine, thymidine, 2-aminoethanol, glycerol and DL- $\alpha$-glycerol phosphate. Does not oxidize $\alpha$ cyclodextrin, dextrin, glycogen, $N$-acetyl-D-galactosamine, $N$-acetyl-D-glucosamine, adonitol, L-arabinose, D-arabitol, cellobiose, $\mathrm{D}$-fructose, L-fucose, $\mathrm{D}$-galactose, gentiobiose, $\alpha$ D-glucose, myo-inositol, $\alpha$-D-lactose, lactulose, maltose, $\mathrm{D}$ mannose, methyl $\beta$-D-glucoside, D-psicose, raffinose, sucrose, trehalose, xylitol, pyruvic acid methyl ester, succinic acid monomethyl ester, D-galacturonic acid, Dgluconic acid, D-glucosaminic acid, $\alpha$-hydroxybutyric acid, $\gamma$-hydroxybutyric acid, $p$-hydroxyphenylacetic acid, $\alpha$ ketobutyric acid, $\alpha$-ketoglutaric acid, $\alpha$-ketovaleric acid, malonic acid, propionic acid, quinic acid, D-saccharic acid, sebacic acid, succinic acid, bromosuccinic acid, glucuronamide, alaninamide, D-alanine, L-asparagine, L-glutamic acid, glycyl L-aspartic acid, glycyl L-glutamic acid, Lhistidine, hydroxy-L-proline, L-leucine, L-phenylalanine, L-proline, D-serine, L-serine, DL-carnitine, inosine, phenylethylamine, putrescine, 2,3-butanediol, $\alpha$-D-glucose 1phosphate or D-glucose 6-phosphate. Resistant to streptomycin and sulfamethoxazole plus trimethoprim, and sensitive to ampicillin, chloramphenicol, gentamicin, kanamycin, nalidixic acid, novobiocin, rifampicin, penicillin $\mathrm{G}$ and tetracycline. Predominant fatty acids are summed feature $3(16: 1 \omega 7 c$ and/or iso-15:0 2-OH), 16:0 and $18: 1 \omega 7 c$. The DNA G+C content of the type strain is $63.4 \mathrm{~mol} \%$.

The type strain, CS $-6^{\mathrm{T}}\left(=\mathrm{LMG} 24215^{\mathrm{T}}=\right.$ BCRC $\left.17729^{\mathrm{T}}\right)$, was isolated from a water sample collected from a spring located inside Nature Valley, Hsinchu County, Taiwan. 


\section{Acknowledgements}

W.-M. C. was supported by grants from the National Science Council, Taipei, Taiwan, Republic of China (NSC 95-2320-B-022-001-MY2 and 96-2313-B-022-001-MY3).

\section{References}

Chen, W. M., Laevens, S., Lee, T. M., Coenye, T., de Vos, P., Mergeay, M. \& Vandamme, P. (2001). Ralstonia taiwanensis sp. nov., isolated from root nodules of Mimosa species and sputum of a cystic fibrosis patient. Int J Syst Evol Microbiol 51, 1729-1735.

Chung, Y. C., Kobayashi, T., Kanai, H., Akiba, T. \& Kudo, T. (1995). Purification and properties of extracellular amylase from the hyperthermophilic archeon Thermococccus profundus DT5432. Appl Environ Microbiol 61, 1502-1506.

Ezaki, T., Hashimoto, Y. \& Yabuuchi, E. (1989). Fluorometric deoxyribonucleic acid-deoxyribonucleic acid hybridization in microdilution wells as an alternative to membrane filter hybridization in which radioisotopes are used to determine genetic relatedness among bacterial strains. Int J Syst Bacteriol 39, 224-229.

Felsenstein, J. (1981). Evolutionary trees from DNA sequences: a maximum likelihood approach. J Mol Evol 17, 368-376.

GCG (1995). Wisconsin Package Version 8.1 Program Manual. Madison, WI: Genetics Computer Group.

Gerhardt, P., Murray, R. G. E., Wood, W. A. \& Krieg, N. R. (editors) (1994). Methods for General and Molecular Bacteriology. Washington, DC: American Society for Microbiology.

Hall, T. A. (1999). BioEdit: a user-friendly biological sequence alignment editor and analysis program for Windows 95/98/NT. Nucleic Acids Symp Ser 41, 95-98.
Jukes, T. H. \& Cantor, C. R. (1969). Evolution of protein molecules. In Mammalian Protein Metabolism, vol. 3, pp. 21-132. Edited by H. N. Munro. New York: Academic Press.

Kalmbach, S., Manz, W., Wecke, J. \& Szewzyk, U. (1999). Aquabacterium gen. nov., with description of Aquabacterium citratiphilum sp. nov., Aquabacterium parvum sp. nov. and Aquabacterium commune sp. nov., three in situ dominant bacterial species from the Berlin drinking water system. Int J Syst Bacteriol 49, 769-777.

Kluge, A. G. \& Farris, J. S. (1969). Quantitative phyletics and the evolution of anurans. Syst Zool 18, 1-32.

Kumar, S., Tamura, K. \& Nei, M. (2004). MEGA3: integrated software for molecular evolutionary genetics analysis and sequence alignment. Brief Bioinform 5, 150-163.

Lányi, B. (1987). Classical and rapid identification methods for medically important bacteria. Methods Microbiol 19, 1-67.

MacFaddin, J. F. (2000). Biochemical Tests for the Identification of Medical Bacteria, 3rd edn. Baltimore: Williams \& Wilkins.

Mesbah, M., Premachandran, U. \& Whitman, W. B. (1989). Precise measurement of the $\mathrm{G}+\mathrm{C}$ content of deoxyribonucleic acid by highperformance liquid chromatography. Int J Syst Bacteriol 39, 159-167.

Powers, E. M. (1995). Efficacy of the Ryu nonstaining $\mathrm{KOH}$ technique for rapidly determining gram reactions of food-borne and waterborne bacteria and yeasts. Appl Environ Microbiol 61, 3756-3758.

Saitou, N. \& Nei, M. (1987). The neighbor-joining method: a new method for constructing phylogenetic trees. Mol Biol Evol 4, 406-425.

Sasser, M. (1990). Identification of bacteria by gas chromatography of cellular fatty acids, MIDI Technical Note 101. Newark, DE: MIDI Inc.

Stackebrandt, E. \& Goebel, B. M. (1994). Taxonomic note: a place for DNA-DNA reassociation and $16 \mathrm{~S}$ rRNA sequence analysis in the present species definition in bacteriology. Int J Syst Bacteriol 44, 846849. 